\title{
DEFINING "DUTY TO THE PUBLIC" WITHIN CANADIAN ENGINEERING PROFESSIONAL CODES OF ETHICS
}

\author{
Emma Jane Randall and David S. Strong \\ Queen's University \\ 14ejr1@queensu.ca and david.strong@queensu.ca
}

\begin{abstract}
What does is it mean for an engineer to uphold their "duty to the public" [1]? The reality is that each person may have a unique interpretation of the concept of an engineer's responsibility to the public based upon their unique experiences, education, values, and beliefs. When considering the concept of an engineer's "Duty to the Public" within the realm of professional engineering ethics codes, there exists a need for a more universal understanding of this concept in order to ensure ethical practice [2]. This need is particularly critical in terms of environmental responsibility within engineering practice as currently there is minimal ethical framework within Canadian professional engineering ethics codes relating to how to act in the best interest of the public with respect to environmental ethical dilemmas [1] [3].

This paper provides a literature review and proposes a multi-perspective, mixed methods research study to learn more about how individuals interpret the concept of an engineer's "Duty to the Public", and the role of environmental responsibility within this concept. By gaining a better understanding of the similarities and variances of how stakeholders interpret engineers' responsibility to the public, it will be possible to identify whether current professional engineering ethics codes are fulfilling their objectives, and if not, to suggest how such codes and Engineering Ethics Education (EEE) might be adapted in future to better address the needs of the public.
\end{abstract}

Keywords: Engineering Ethics, Environmental Responsibility, Professional Ethics, CEAB Graduate Attribute 10, Engineering Ethics Education

\section{INTRODUCTION}

Currently, professional engineering codes of ethics (PECoEs) across Canada are largely prone to

CEEA-ACEG21; Paper175

University of Prince Edward Island; June 21 - 23, 2021- 1 of 6 - interpretation because the language they use and the principles that they outline are abstract. In particular, there is no definition for terms and phrases such as, "Duty to the Public", "Fidelity to Public Needs", and "Public Welfare". Consequently, there is not currently a definitive universal understanding of the underlying concept of an engineer's duty to the public, to which these phrases elude. This results in a vast potential for variance in how individuals interpret these phrases and the principle which they represent, based upon personal experience, individual value systems and beliefs, personal priorities, etcetera. Without having collectively agreed upon definitions and interpretation of these terms and the concept which they represent, PECoEs have grey areas with regards to guiding engineers in ethical practice. This creates stress for engineers making ethical decisions within the field of engineering, as well as potentially facilitates ethically ambiguous practices which are difficult to legally address without stricter guidelines.

This paper proposes a study which aims to increase understanding of the concept of an engineer's duty to the public by investigating how various stakeholders understand this concept. The literature review of this paper will cover professional codes of ethics, the regulation of engineering in Canada, and the current state and objectives of engineering ethics education in Canada. The research direction, scope, and potential significance and application of the results will then be discussed in more detail to conclude.

\section{DEFINITIONS AND RESEARCH SCOPE}

The scope of this project is currently focussed within Canada, but given the similarity of undergraduate engineering program accreditation between Canada and the United States (US), American research may also be used to help inform this study [3] [4]. The initial pilot phase of the research study as currently proposed will occur in the province of Ontario, Canada. Ontario was chosen because the researcher is situated within Ontario and close proximity may be helpful when contacting participants. Furthermore, Ontario has a high 
concentration of universities with engineering undergraduate programs relative to other provinces and territories in Canada, as well as an active, diverse engineering industry [5]. Upon completion of the pilot phase, the research study will be extended to other Canadian provinces and territories.

In general, ethics may be divided into two major categories: moral ethics and professional ethics [6]. For the purpose of this study, these terms will be defined as follows:

Moral ethics are defined as standards of conduct that apply to everyone rather than only to members of a special group. Ideally, these standards are ones that every rational person wants every other to follow, even if everyone else's following them would mean that they would have to do the same [6]. Professional ethics are defined as special morally permissible standards of conduct that, ideally, every member of a profession wants every other member to follow, even if that would mean that they would have to do the same [6].

When using the term 'Engineering Ethics Education (EEE)' throughout this paper, this refers to the conveyance of professional engineering ethics to undergraduate engineering students.

\section{LITERATURE REVIEW}

\subsection{The Current State and Objective of EEE in Canada}

The general objective of teaching engineering ethics in undergraduate programs is to produce ethically aware and responsible engineers, with the greater intention of stimulating ethical practice [7] [8] [9]. The Canadian Engineering Accreditation Board (CEAB) requires that graduating engineering students must have an "ability to apply professional ethics, accountability, and equity" [3].

As ethics may generally be considered an individual domain, there is disagreement surrounding the content of EEE curriculum. This stems from both variance in individuals' moral ethical beliefs, and a concern that in teaching ethics there is potential for indoctrination of students to a specific belief system [10]. However, it is agreed in Canada that some formal professional ethics education is essential for engineers, just as it is for other professions such as medicine, accounting, and law [3] [11] [6] [12].

One major barrier to standardizing EEE, is that there is currently no universally agreed upon interpretation of the objectives of EEE [13] [14] [8]. The consensus between the majority of perspectives on EEE curriculum is that at a minimum, professional ethics should be taught to students [13] [3] [7] [4]. This may be summarized as:
1. Awareness of ethical responsibility as an engineer.

2. Knowledge about professional engineering codes and regulations.

3. Ability to apply knowledge of codes and regulations for ethical decision making within an engineering context.

Many researchers believe that although the above objectives provide a strong foundation, more is needed to teach engineering students to navigate the complex nature of engineering ethics within a societal context [7] [2] [8] [15]. Harris et al. proposed a list of more specific objectives for EEE [6]:

1. Stimulate the ethical imagination of students

2. Help students recognize ethical issues

3. Help students analyze key ethical concepts and principles

4. Help students deal with ethical disagreement, ambiguity and vagueness

5. Encourage students to take ethical responsibility seriously

6. Increase student sensitivity to ethical issues

7. Increase student knowledge of relevant standards

8. Improve ethical judgement

9. Increase ethical will-power

Both Lynch and Haws discussed features of EEE content that may extend beyond those that fall exclusively under professional ethics [15] [14]:

1. Professional engineering ethical codes

2. Theoretical reasoning and moral theories

3. Humanist readings

4. Case studies

5. Ethical heuristics

6. Service learning

Another way to regard engineering ethics is to dissect professional ethics philosophically into micro-ethics and macro-ethics. As summarized by $\mathrm{Li}$ and $\mathrm{Fu}$, "micro-ethics considers individuals and internal relations of the engineering profession" whereas, "Macro-ethics concerns the collective social responsibility of the profession to make societal decisions about technology or the social context in which engineers are practicing" [12] [16]. In the past, micro-ethics have been the primary focus of EEE curriculum, but many individuals see micro-ethics as an oversimplification of engineering ethics and believe that curriculum should shift to incorporate a more macroethics approach [13] [2] [17] [7].

To recapitulate, although there are commonalities between various viewpoints, there is diverse interpretation of what the curriculum and objectives of EEE should incorporate. It is important to understand 
the array of present interpretations of EEE within Canada to understand the perceived ethical responsibility of engineers.

\subsection{Professional Codes of Ethics}

The purpose of a professional code of ethics is to provide a set of governing principles or values which may be used to guide professional decisions, or to judge the ethical appropriateness of specific conduct within a professional environment. Across various professions, professional codes of ethics may be developed and implemented with different philosophies. Generally, professional codes of ethics are presented as either broad guiding principles, or as a more definitive set of rules with enforceability in regard to legal matters. [18] [19]

In Canada, professional engineering codes of ethics fall towards the category of broad guiding principles [19]. Engineers Canada recommends that engineers, "interpret the essence of the underlying principles [of professional engineering codes of ethics] within their daily decision-making situations in a dynamic manner, responsive to the needs of the situation" [19].

\subsection{The Regulation of Engineering in Canada}

In Canada, engineering is a self-regulated profession at a provincial or territorial level. This means that each province and territory has its own laws and Professional Code of Ethics to regulate engineering practice. These rules and regulations stem from the general overseeing body, Engineers Canada, which provides guidelines for each province/territory to base their legislation upon. Being self-regulated, the responsibility to outline and uphold professional ethics falls directly upon licensed engineers in Canada, rather than upon an external regulatory body. When becoming licensed as an engineer in Canada, individuals commit to abiding by the laws and Professional Code of Ethics decreed by the province or territory they become licensed to practice within. [19]

Engineering licencing is done at a provincial level in Canada via a process where candidates complete a certain amount of industry experience under the supervision of a professional engineer, and then must pass the National Professional Practice Exam (NPPE) [19] [11]. The NPPE emphasizes engineering ethics, engineering law, professional liability, and professional practice standards [6] [11]. Once a person passes the NPPE and obtains the required experience and duration working under the supervision of a professional engineer, they are eligible to apply to become a licenced engineer within the province/territory they are

CEEA-ACEG21; Paper175

University of Prince Edward Island; June 21 -23, 2021- 3 of 6 - registered within. With the exception of Ontario, all provincial and territorial engineering associations have mandatory Continuing Professional Development (CPD) to maintain or renew an engineering licence [20]. Programs in place require licence holders to complete 60 hours of CPD over 3 years [21]. Professional Engineers of Ontario (PEO) has implemented a program called Professional Evaluation and Knowledge (PEAK) which encourages individualized CPD for engineers licenced in Ontario, but this program is currently not mandatory [22]. Mandatory CPD requirements are common across other professions in Canada such as law and accounting, which both require a minimum of between 12 - 20 hours of Continuing Professional Development (CPD) annually to maintain an active licence in Ontario [23] [24]. With no mandatory requirement for further training, the minimum standard for engineers' formal ethics education in Ontario is that which they receive in their undergraduate program.

\section{PROPOSED RESEARCH DIRECTION}

\subsection{Research Purpose}

The purpose of this study will be to learn more about how various stakeholders interpret the concept of an engineers" "Duty to the Public", and to derive common attributes in how individuals define this phrase and others such as "Fidelity to Public Needs", and "Public Welfare", from an engineering standpoint. Moreover, stakeholders' view of the engineering industry's responsibility to the environment will be investigated. A main point of the study will be to determine if stakeholders view environmental responsibility to fall under the concept "Duty to the Public".

\subsection{Proposed Research Questions}

In the following questions the term 'stakeholders' corresponds to groups including Licensed Engineers, Engineering Faculty, Engineering Students, Engineers in Training, Canadian and Provincial Engineering SelfRegulating Bodies, and the Canadian Government. The purpose behind identifying and selecting these participant groups shall be further discussed in Section 4.3. The primary questions that will guide this research are:

1. How do stakeholders interpret the phrases and underlying concepts of, "Duty to the Public", "Fidelity to Public Needs", and "Public Welfare"? 
2. How do stakeholders' interpretations of the phrases and underlying concepts of, "Duty to the Public", "Fidelity to Public Needs", and "Public Welfare", vary?

3. How is the engineering industry's responsibility to the environment interpreted by stakeholders?

4. What role does environmental responsibility play for the engineering industry within the concept of "Duty to the Public"?

\subsection{Proposed Participants and Site of Research Study}

As discussed previously, this research study will be piloted within the province of Ontario, Canada.

However, data collection will occur remotely via virtual methods to abide by the social distancing guidelines in affect as a result of the Covid-19 Pandemic [25]. Remote data collection may enable the scope to increase to a multi-Province/Territory study.

There are several key stakeholder groups that have been selected for participation within this study. These stakeholder groups are listed, defined, and the reason for their selection has been detailed in Table 1.

Table 1: Definition of identified stakeholder groups and reasoning for their selection.

\begin{tabular}{|c|c|c|}
\hline Stakeholder & Definition & Reason for Selection \\
\hline $\begin{array}{l}\text { Licensed } \\
\text { Engineers }\end{array}$ & $\begin{array}{l}\text { Engineers who } \\
\text { have achieved } \\
\text { and maintained } \\
\text { an active license } \\
\text { to practice as an } \\
\text { engineer within } \\
\text { Ontario. }\end{array}$ & $\begin{array}{l}\text { The opinions of these } \\
\text { individuals represent } \\
\text { the values of the } \\
\text { current engineering } \\
\text { industry. They have } \\
\text { all committed to } \\
\text { abide by current } \\
\text { PECoEs. Licensed } \\
\text { engineers have voting } \\
\text { power within self- } \\
\text { regulating bodies and } \\
\text { so they are capable of } \\
\text { impacting decisions } \\
\text { regarding PECoEs. }\end{array}$ \\
\hline $\begin{array}{l}\text { Engineers in } \\
\text { Training }\end{array}$ & $\begin{array}{l}\text { Individuals who } \\
\text { have graduated } \\
\text { from an } \\
\text { accredited } \\
\text { engineering } \\
\text { program and are } \\
\text { now working to } \\
\text { fulfill their } \\
\text { engineering } \\
\text { licensing criteria. }\end{array}$ & $\begin{array}{l}\text { These individuals } \\
\text { represent the near- } \\
\text { future values of } \\
\text { engineering industry. } \\
\text { Once licensed they } \\
\text { will have potential } \\
\text { influence over the } \\
\text { PECoEs via direct } \\
\text { involvement and } \\
\text { voting power. }\end{array}$ \\
\hline $\begin{array}{l}\text { Engineering } \\
\text { Faculty }\end{array}$ & $\begin{array}{l}\text { Individuals who } \\
\text { teach within an } \\
\text { undergraduate }\end{array}$ & $\begin{array}{l}\text { These individuals } \\
\text { teach professional } \\
\text { values to future } \\
\text { engineers. Their }\end{array}$ \\
\hline
\end{tabular}

CEEA-ACEG21; Paper175

University of Prince Edward Island; June 21 -23, 2021- 4 of $6-$

\begin{tabular}{|c|c|c|}
\hline Stakeholder & Definition & Reason for Selection \\
\hline & $\begin{array}{l}\text { engineering } \\
\text { program. }\end{array}$ & $\begin{array}{l}\text { opinions may shape } \\
\text { the next generation of } \\
\text { engineers. } \\
\text { Furthermore, all } \\
\text { licensed individuals } \\
\text { have voting power } \\
\text { and potential } \\
\text { influence on PECoEs. }\end{array}$ \\
\hline $\begin{array}{l}\text { Engineering } \\
\text { Students }\end{array}$ & $\begin{array}{l}\text { Individuals in } \\
\text { the process of } \\
\text { earning their } \\
\text { undergraduate or } \\
\text { graduate degree } \\
\text { in engineering. }\end{array}$ & $\begin{array}{l}\text { These individuals } \\
\text { represent the future } \\
\text { values of engineering } \\
\text { industry. They will } \\
\text { have voting power } \\
\text { once they become } \\
\text { licensed and then will } \\
\text { have potential } \\
\text { influence over the } \\
\text { PECoEs. }\end{array}$ \\
\hline $\begin{array}{l}\text { Engineers } \\
\text { Canada }\end{array}$ & $\begin{array}{l}\text { The national } \\
\text { self-regulating } \\
\text { body for } \\
\text { professional } \\
\text { engineers in } \\
\text { Canada. }\end{array}$ & $\begin{array}{l}\text { This self-regulating } \\
\text { body oversees the } \\
\text { provincial/territorial } \\
\text { self-regulating bodies } \\
\text { of professional } \\
\text { engineers. They } \\
\text { provide the guidelines } \\
\text { for the PECoEs which } \\
\text { shape the } \\
\text { provincial/territorial } \\
\text { PECoEs. }\end{array}$ \\
\hline $\begin{array}{l}\text { Provincial } \\
\text { and } \\
\text { Territorial } \\
\text { Engineering } \\
\text { Associations }\end{array}$ & $\begin{array}{l}\text { The provincial } \\
\text { and territorial } \\
\text { self-regulating } \\
\text { bodies for } \\
\text { professional } \\
\text { engineers in } \\
\text { Canada }\end{array}$ & $\begin{array}{l}\text { These self-regulating } \\
\text { bodies oversee the } \\
\text { professional } \\
\text { engineers of Canada. } \\
\text { They are responsible } \\
\text { for representing the } \\
\text { engineers of their } \\
\text { respective } \\
\text { province/territory and } \\
\text { for producing and } \\
\text { updating their } \\
\text { provincial/territorial } \\
\text { PECoEs. }\end{array}$ \\
\hline $\begin{array}{l}\text { Canadian } \\
\text { Government }\end{array}$ & $\begin{array}{l}\text { The federal } \\
\text { government of } \\
\text { Canada } \\
\text { representing the } \\
\text { interests of the } \\
\text { Canadian public. }\end{array}$ & $\begin{array}{l}\text { The public is the } \\
\text { primary stakeholder } \\
\text { within the concept of } \\
\text { "Duty to the Public". } \\
\text { The government of } \\
\text { Canada is the voice of } \\
\text { the public and they } \\
\text { require that PECoEs } \\
\text { reflect the public's } \\
\text { needs resulting in } \\
\text { ethically responsible } \\
\text { engineering practice. }\end{array}$ \\
\hline
\end{tabular}

Ideally, there will be relatively equal representation for each of these stakeholder groups. As discussed previously, the goal of this study will be to generate a large amount of data so as to be able to derive collective themes rather than individual opinions. With this in 
mind, it is unclear what number of participants within each stakeholder group will be required to achieve this objective. Currently, it is thought that recruiting a minimum of 50 participants within each stakeholder group (with the exception of regulatory bodies) will be a satisfactory foundation. For regulatory bodies, within 2-5 participants may be an acceptable range as with the nature of these positions, members have already been selected to be representative of a larger community.

\subsection{Proposed Methods of Research Study}

Primarily, data will be collected using a survey distributed electronically. The reason that this tool has been chosen is because the benefit of this study lies in collecting a large amount of data from various widespread participants. In this case, a self-written method for data collection is more conducive to collecting large amounts of data in a manageable format, as opposed to other methods such as data collection via interview or observation. Furthermore, having a digital instrument will allow for easy distribution of the research tool, and for data to be collected from participants remotely even if in-person meetings and gatherings are restricted due to present physicaldistancing conditions resulting from the COVID-19 pandemic [25]. If restrictions upon in-person gatherings are lifted within the study timeframe, there may also be potential to conduct focus groups or interviews with various stakeholders. These options will be further explored throughout the refinement of the study.

As discussed earlier, the study is intended to be a mixed methods format. The initial phase of the tool will ask participants how they define various phrases such as "Duty to the Public", "Fidelity to Public Needs", and "Public Welfare", within an engineering context. The purpose of this phase is to identify key elements that participants view to constitute the concept of the engineer's duty to the public. The second phase of the tool will ask participants specifically how they view the engineer's professional responsibility to the environment. The purpose of this is to identify what participants understand to be engineering as an industry's obligation to the environment throughout ethical practice. The final part of the survey will ask specifically if participants view environmental responsibility to fall under the concept of the engineer's duty to the public. The purpose of this final phase will be to gain insight into whether participants explicitly view environmental responsibility to fall under the concept of the engineer's duty to the public. One interesting result will be to see if there is variance between participant's phase one and phase three responses.

CEEA-ACEG21; Paper175

University of Prince Edward Island; June 21 - 23, 2021- 5 of 6 -

\section{CONCLUSIONS}

It is clear that there is a need to better understand how various stakeholders interpret engineers' duty to the public, in order to ensure engineering practice that best meets the publics' needs within Canada.

This paper provides preliminary research regarding the educational approach, code structure, and regulation of engineering ethics within Canada, and proposes a study which would determine if there are mass variances in how various stakeholders understand the concept of an engineer's duty to the public. The results of this study may help inform whether current professional engineering codes of ethics are meeting their objective of providing clear values to guide ethical practice within Canada.

\section{REFERENCES}

[1] Professional Engineers Ontario, "Professional Engineers Ontario," 2019. [Online]. Available: https://www.peo.on.ca/about-peo/what-is-peo.

[2] R. Cindy, R. Doug, R. Sacks and M. Klassen, "Engineering Ethics Education: More than a CEAB Requirement," in Canadian Engineering Education Association, Hamilton, ON., 2015.

[3] Engineers Canada, "2018 Accreditation Criteria and Procedures," November 2018. [Online].

Available:

https://engineerscanada.ca/sites/default/files/accre ditation/Accreditation-criteria-procedures2018.pdf.

[4] Accreditation Board for Engineering and Technology, "ABET Accreditation," November 2018. [Online]. Available: https://www .abet.org/accreditation/.

[5] Engineers Canada, "Final Year Engineering Students 2017 Survey - National Results Share: The graduating class of 2017," Engineers Canada, 2017.

[6] A. Roncin, "Thoughts on Engineering Ethics Education in Canada," in Canadian Engineering Education Association, Montreal, 2013.

[7] L. L. Bucciarelli, "Ethics and engineering education," European Journal of Engineering Education, vol. 33, no. 2, pp. 141-149, May 2008.

[8] J. C. E. Harris, M. Davis, M. S. Pritchard and M. J. Robins, "Engineering Ethics: What? Why? How? And When?," Journal of Engineering Education, vol. 85, no. 2, pp. 93-96, April 1996. 
[9] M. A. Holsapple, D. D. Carpenter, J. A. Sutkus, C. J. Finelli and T. S. Harding, "Framing Faculty and Student Discrepencies in Engineering Ethics Education Delivery," Journal of Engineering Education, vol. 101, no. 2, pp. 169-186, April 2012.

[10] S. K. A. Pfatteicher, "Teaching vs. Preaching: EC2000 and the Engineering Education Dilemma," Journal of Engineering Education, vol. 90, no. 2, pp. 137-142, 2001.

[11] Engineers Canada, "Overview of the Licensing Process," Engineers Canada, [Online]. Available: https://engineerscanada.ca/become-anengineer/overview-of-licensing-process.

[12] J. Li and S. Fu, "A Systematic Approach to Engineering Ethics Education," Science and Engineering Ethics, vol. 18, no. 2, pp. 339-349, June 2012.

[13] B. Newberry, "The Dilemma of Ethics in Engineering Education," Science and Engineering Ethics, vol. 10, no. 2, pp. 343-351, 2004.

[14] W. Lynch, "Teaching Engineering Ethics in the United States," IEEE Technology and Society Magazine, vol. 16, no. 4, pp. 27-36, 1998.

[15] D. R. Haws, "Ethics Instruction in Engineering Education: A (Mini) Meta-Analysis," Journal of Engineering Education, vol. 90, no. 2, pp. 137$142,2001$.

[16] J. Herkert, J. Wetmore, H. Canary and K. Ellison, "Integrating microethics nad macroethics in graduate science and engineering education: Developing instructional models".

[17] J. S. Cicek, P. Labossiere and S. Ingram, "Examining Fourth Year Engineering Student Perceptions of Graduate Attribute Competencies: Year Two," in Canadian Engineering Education Association, Canmore, 2014.

[18] M. Davis, "What can we learn by looking for the first code of professional ethics?," Theoretical Medicine and Bioethics, no. 24, p. 433-454, 2003.

[19] Engineers Canada, "Public Guideline on the Code of Ethics," Engineers Canada, 2016.

[20] C. Roney, B. Miller, S. McCann, C. Maltby, M. Mariotti, T. Ing, R. Hohendorf, A. Ghobeity, D. Brown and A. Bergeron, "Continuing Professional Development, Competence and Quality Assurance Task Force," November 2015. [Online]. Available: https://www.peo.on.ca/continuing-professionaldevelopment-competence-and-quality-assurancetask-force.

CEEA-ACEG21; Paper175

University of Prince Edward Island; June 21 - 23, 2021- 6 of 6 -
[21] Engineers \& Geoscientists British Columbia, "Continuing Education - Program Overview," 2021. [Online]. Available:

https://www.egbc.ca/ContinuingEducation/Continuing-Education/FrequentlyAsked-Questions.

[22] Professional Engineers Ontario, "Practice Evaluation and Knowledge Program," 2019. [Online]. Available: https://www.peo.on.ca/licence-holders/practiceevaluation-and-knowledge-program.

[23] Chartered Professional Accountants of Ontario, "A Simple Guide to CPD Requirements," Chartered Professional Accountants of Ontario, 2019.

[24] Law Society of Ontario, "Continuing Professional Development Requirement," Law Society of Ontario, 2017. [Online]. Available: https://lso.ca/lawyers/enhancingcompetence/continuing-professionaldevelopment-requirement.

[25] World Health Organization, "Coronavirus disease (COVID-19) pandemic," World Health Organization, 2021. [Online]. Available: https:/www.who.int/emergencies/diseases/novelcoronavirus-2019. 